\title{
Investigation of the relationship between critical thinking levels and academic achievement levels of students in Faculty of Sports Science
}

\author{
Mihriay MUSA \\ Department of Coach, Faculty of Sport Science, Usak University, Turkey.
}

Received 6 March, 2020; Accepted 25 June, 2020

\begin{abstract}
This study aims to investigate the relationship between critical thinking levels and academic achievement levels of the students in faculty of sports science. The research population consists of 1170 students studying at the Usak University, Faculty of Sport Sciences in the fall semester of 20192020. The sample group consisted of 334 students selected from the university by random sampling method through voluntary participation. In the research, California Critical Thinking Disposition Inventory (CCTDI-R) which was originally developed by Facione et al. and whose Turkish validityreliability study was conducted by Kokdemir was shortened. The Turkish version of it (CCTDI- R) was used. The academic achievement levels of the students were obtained through Usak University Student Information System (SIS). Frequency, percentage, and arithmetic average was used to evaluate academic grade point average and the data obtained with critical thinking tendency scale. Correlation analysis was used to determine the relationship between variables and regression analysis was used to determine the effect of independent variable on dependent variable. According to the results, it is revealed that there is a positive relationship between students' critical thinking levels and their academic achievement levels. it is observed that besides, a positive correlation was observed between students' academic achievements and their tendency to be careful about potentially problematic situations in their critical thinking skills sub-dimensions and to use objective evidence even in the face of difficult problems.
\end{abstract}

Key words: Sports science, students, critical thinking, academic achievement.

\section{INTRODUCTION}

People think intrinsically. However, the thought that has not been given a certain norm, it can usually be preconvicted, distorted, biased, ignorant and reductionist. Our quality of life, our production is exactly about the level of our thought quality. A regular and purposeful education system is required for purification of thought and for the thought to reach perfection. Critical thinking is a process in which individuals manage the structures in their thought systems skillfully and bring intellectual standards to those structures, to improve the quality of their thinking methods. Individuals with critical thinking have the following characteristics; they develop crucial

E-mail: mihriay.musa@usak.edu.tr.

Author(s) agree that this article remain permanently open access under the terms of the Creative Commons Attribution License 4.0 International License 
questions and problems. They obtain and interpret relevant data to analyze qualitative ideas effectively. They test the information with the relevant criteria and standards and go near correct results and solutions. By thinking impartially on different thought systems, they think about the assumptions that these systems contain, considering their possible effects and outcomes, and can communicate effectively with other individuals in solving intricate issues. The essence of critical thinking is the autonomous orientation, discipline, monitoring, and verification of the individual's thoughts.

In this study, critical thinking is discussed. In this context, the concepts of thinking skills and critical thinking have been clarified first, and then the interest between the critical thinking levels of the students of the sports sciences and their academic success levels has been revealed through various variables. In the study, a descriptive survey method was used to determine the critical thinking levels of the students of the Faculty of Sport Sciences. The opinions of the students studying at the Faculty of Sports Sciences about their critical thoughts were determined by following the quantitative research methodology.

\section{Critical thought in conceptual dimensions}

It is observed that various studies have been carried out recently both in Turkey and abroad regarding critical thinking ability. The main reason for this occurrence is due to the place of critical thinking in educational programs. This is because when the education programs are examined, it is accepted that the students who receive an education are "critical thinkers" (Smith, 2003: 27). Critical thinking, which is an output in the Education Program needs to be explained with its conceptual dimensions. According to Kalayci (2001: 7), critical thinking is "the systematic way of thinking, where the problem is evaluated with the criteria put forward, the judgment is made after reaching all data". According to Doğanay (2007: 301), it is explained as "important highlevel thinking involving the process of extracting meaning from them by questioning the accuracy of the information". On the other hand, Paul and Elder (2006, p. 3 ) explained that "it is a process in which the thinking method improves the quality of the method by mastering the structures in the thought system of the person and bringing intellectual standards to these structures". According to Pirozzi (2003: 197), it is "thinking very carefully and logically about any situation, issue, decision, problem or event". According to Patrick (1986), "it is necessary to be a good intellectual citizen in a free society". For this purpose, he emphasized that it is important to study the truth in the format, where criticism and asking questions are encouraged. According to Nosich (2015), critical thinking consists of a threedimensional structure. The first dimension is to ask questions, the second dimension is to try to solve the questions by understanding the logic, and the last dimension is to believe in the results of critical thinking.

It is seen that the researchers who think about critical thinking have various differences of opinion about the concept and the scope of the concept. When the boundaries of the concept of critical thinking and the common points of its features are examined; it is a logical systematic way of thinking; It is necessary to ask questions and criticize in order to make sense of knowledge in mind; It evolves towards an opinion that it is a high level of thinking. On the other hand, Kökdemir (2012), made a contribution to the characteristics of critical thinking, in his study, where he investigated the problem statement about whether critical thinking was teachable.The results he achieved were as follows: critical thinking is both a skill that determines academic performance and that this skill is a cognitive process that can be gained with effective methods.

Research to date shows that critical thinking can be taught. When the studies on critical thinking in the literature are analyzed, it is seen that they are divided into two main groups. Studies on the features of the concept and studies on the concept of the concept. Studies on the features of the concept are studies in which critical thinking abilities, tendencies, levels, understandings, and attitudes are revealed according to different variables. These studies are the ones that investigate the effect of this education on the critical thinking skills, attitudes and variables determined according to the research problem after a critical thinkingbased education and training process. In these studies, primary school, middle school, high school students, teacher candidates, teachers or academicians were chosen as sample mass. The second group, on the other hand, is theoretical studies targeting critical thinking abilities regarding the concept.

It is likely to encounter both national and international studies in literature where tendency, attitude, and skill levels are analyzed according to different variables. There are sample mass investigated related to this topic (Al-degether, 2009, 2012; Coffman, 2013; Çevik, 2013; Deniz, 2009; Derrick-Telemaque, 2014; Gülveren, 2007; Karakoç, 2011; Karali, 2012; Kasimoğlu, 2013; Korur, 2014; Özen, 2013; Öztürk, 2006; Tufan, 2008). After a critical thinking-based education-training process, the studies examining the effect of this education on the variables determined according to critical thinking skills, attitudes and research problem are examined in details according to the sample groups; as well as studies with prospective teachers and university students (Aybek, 2006; Bayram, 2015; Coşkun, 2011; Güner, 2015; Kalelioğlu, 2011; Kanbay, 2013; Kökdemir, 2003; Obay, 2009; Özdemir, 2005; Schreglmann, 2011; ValdesCorbeil, 2005; Yeh, 1997; Yildirim, 2010; Yücel, 2008); and studies with teachers (Adams, 2013; Dağli, 2008; Dolapci, 2009; Moreyra, 1991; Ünlü, 2017) were found. 
After these studies, there are two issues that researchers especially emphasize. The development of critical thinking skills can only be achieved by implementing a program based on critical thinking. Within the education system, these skills can be gained by students through methods and techniques to be arranged in line with the intelligence and abilities of students at all levels of education (Yağci, 2008, p.37). In order to teach critical thinking, students must be actively involved in various activities. Critical thinking cannot be taught only by explaining what critical thinking is, its importance and how to apply should be taught too (Van Gelder, 2005). The purpose of this study is to reveal the interest between the critical thinking levels of the faculty of sports science students and their academic success levels through various variables. The independent variables for the study are the conditions of doing sports under license and the branches of sports they do. The sub-dimensions of critical thinking are open-mindedness sub-dimension, academic success analyticalness sub-dimension, truthseeking sub-dimension, curiosity sub-dimension, selfconfidence sub-dimension, and systematic subdimension.

\section{METHODOLOGY}

This research is in a relational screening model. The scanning models are research approaches that aim to describe a situation that exists in the past or still exists. In the screening model researches, the opinions of the participants about a topic or event, interest, skill, ability, and attitude were defined.

\section{Study group}

The universe of the research consists of 1170 students studying at Uşak University, Faculty of Sport Sciences in the fall semester of 2019-2020. The sample group consisted of 334 students selected from this population by random sampling method through voluntary participation.

\section{Data collection tools}

To determine the critical thinking skills of prospective teachers, the California Critical Thinking Trends Scale (CCTDI), which was developed as a result of the Delphi project organized by the American Philosophy Association in 1990 was used. Unlike similar critical thinking scales, CCTDI was prepared not to measure skill, but to evaluate a person's critical thinking disposition or, more specifically, a level of critical thinking (Kökdemir, 2003). The scale was translated into Turkish (CCTDI) by Kökdemir (2003), and factor, validity and reliability analyses were performed. The total variance explained by the new scale, consisting of a total of 51 subdimensions and 51 items, 29 positive and 22 negatives, is $36.13 \%$. Internal consistency coefficients of each dimension Analyticalness Scale and Open-Mindedness Scale, 0.75; Curiosity Subscale, 0.78; Self Confidence Scale, 0.77; The Right Search Scale, 0.61; and Systematics Subscale, 0.63. In the Likert type and six-interval scale, after the negative items were scored in the opposite direction, the answers $(1=$ Strongly disagree, 2 = Disagree, $3=$ Partially disagree, 4 = Partially agree, $5=$ Agree, $6=$ Strongly agree) given to the scale were added and the raw scores were calculated for each subscale, and these raw scores were converted into a standard score after being divided by the number of questions and multiplied by 10 to a standard score that received the lowest value as 6 and the highest 60 . The lowest and highest possible values for all subscales are fixed. Facione et al. (1998) and Akt. Kökdemir (2003) opine that individuals with a score of less than 40 for each subscale have low critical thinking tendencies and those with a score of 50 or higher have a critical thinking tendency. Therefore, when CCTDI is evaluated as a whole, it can be said that the people who have less than $240(40 \times 6)$ general tendency to think critically, and those who have a score of more than $300(50 \mathrm{x}$ 6) are high (Kökdemir, 2003).

\section{Analysis of the data}

By using SPSS for Windows 17.0 packaged program, correlation analysis was performed at the frequency, percentage, arithmetic mean and ( $p<0.05),(p<0.01)$ significance level to evaluate the data collected with the critical thinking disposition scale and academic grade averages. Regression analysis was carried out at the significance level $(p<0.01)$ to determine the effect of variables independent of the variables that were associated with them on the dependent variable (Table 1). There is a weak positive relationship between students' critical thinking levels and academic achievement levels $(p<0.05)$. There is no relationship between students' critical thinking levels and sports branches ( $p>0.05$ ). There is no relationship between students' critical thinking levels and being licensed athletes ( $p>0.05$ ) (Table 2).

There is a positive weak relationship between students' analyticalness sub-dimensions and academic achievement levels ( $p$ $<0.05)$. There is a positive weak relationship between students' curiosity sub-dimensions and academic achievement levels ( $p$ $<0.01$ ). There is a positive weak relationship between students' selfconfidence sub-level and academic achievement levels $(p<0.01)$. There is no strong relationship between students' open-mindedness sub-dimension and academic achievement levels ( $p>0.05)$. There is no relationship between students' truth-seeking sub-dimension and academic achievement levels ( $p>0.05)$. There is no relationship between students' systematicity sub-dimension and academic achievement levels ( $p>0.05$ ) (Table 3). There is a negatively weak relationship between students' comprehension of truth sub-dimension levels and sports branches $(p<0.05)$. There is a negatively weak relationship between the students' selfconfidence subscale levels and sports branches $(p<0.05)$. There is a negatively weak relationship between students' systematicity subdimension levels and sports branches $(p<0.05)$.

There is no relationship between students' open-mindedness sub-dimension and sports branches ( $p>0.05$ ). There is no relationship between students' analyticalness sub-dimension levels and sports branches ( $p>0.05)$. There is no relationship between students' curiosity sub-dimension levels and sports branches ( $p>$ 0.05 ) (Table 4). There is no relation between the open-mindedness sub-dimension of students and whether they do sports licensed ( $p>$ 0.05). There is no relationship between students' levels of analyticalness sub-dimension and whether they do sports licensed ( $p>0.05$ ). There is no relationship between students' level of searching for truth sub-dimension and whether they are doing licensed sports ( $p>0.05)$. There is no relationship between students' curiosity sub-dimension and whether they do sports licensed ( $p>0.05$ ). There is no relationship between students' selfconfidence sub-level and whether they do sports licensed ( $p>0.05)$. There is no relationship between the systematicity sub-dimension of students and whether they do sports licensed ( $p>0.05$ ) (Tables 5 to 7). 
Table 1. Correlation analysis for the relationship between students' critical thinking levels and academic achievement levels, sports branches and being licensed athletes.

\begin{tabular}{lccc}
\hline Variable & $\mathbf{N}$ & $\mathbf{r}$ & $\mathbf{p}$ \\
\hline Critical thinking level - academic achievement & 334 & 0.116 & $0.034^{*}$ \\
Critical thinking level-sports branches & 334 & -0.064 & 0.806 \\
Critical thinking level- being a licensed athlete & 334 & 0.014 & 0.806 \\
\hline
\end{tabular}

Table 2. Correlation analysis for the relationship between students' critical thinking levels sub-dimensions and academic achievement levels.

\begin{tabular}{lccc}
\hline Variable & N & r & p \\
\hline Open mindedness dimension- academic achievement & 334 & -0.061 & 0.267 \\
Analyticalness sub-dimension- academic achievemet & 334 & 1.107 & $0.050^{*}$ \\
The truth- seeking sub dimension- academic achievement & 334 & -0.026 & 0.616 \\
Curiosity sub dimension- academic achievement & 334 & 0.148 & $0.007^{* *}$ \\
Self confidence dimension- academic achievement & 334 & 0.205 & $0.000^{* *}$ \\
Systematicity sub-dimension- academic achievement & 334 & -0.077 & 0.620 \\
\hline
\end{tabular}

Table 3. Correlation analysis for the relationship between students' critical thinking levels subdimensions and their sports branches.

\begin{tabular}{lccc}
\hline Variable & $\mathbf{N}$ & $\mathbf{~}$ & $\mathbf{p}$ \\
\hline Open mindedness dimension- sports branches & 334 & -0.051 & 0.353 \\
Analyticalness sub-dimension- sports branches & 334 & -0.054 & 0.326 \\
The truth-seeking sub dimension -sports branches & 334 & -0.136 & $0.013^{*}$ \\
Curiosity sub dimension- sports branches & 334 & -0.030 & 0.539 \\
Confidence sub-dimension- sports branches & 334 & -0.112 & $0.040^{*}$ \\
Systematicity sub dimension- sports branches & 334 & -0.123 & $0.025^{*}$ \\
\hline
\end{tabular}

Table 4. Correlation analysis for the relationship between students' critical thinking levels sub-dimensions and being licensed athletes.

\begin{tabular}{lccc}
\hline Variable & N & r & p \\
\hline Open mindedness dimension- being a licensed athlete & 334 & -0.016 & 0.773 \\
Analyticalness sub-dimension- being a licensed athlete & 334 & 0.024 & 0.658 \\
The truth-seeking sub dimension - being a licensed athlete & 334 & -0.001 & 0.988 \\
Curiosity sub dimension- being a licensed athlete & 334 & 0.002 & 0.973 \\
Confidence sub-dimension- being a licensed athlete & 334 & 0.043 & 0.434 \\
Systematicity sub dimension- being a licensed athlete & 334 & 0.028 & 0.604 \\
\hline
\end{tabular}

Table 5. Correlation analysis for the effect of students' sports branches on "Systematicity", A sub-dimension of critical thinking levels.

\begin{tabular}{|c|c|c|c|c|c|}
\hline \multirow{2}{*}{ Sports branches } & \multicolumn{2}{|c|}{ Non-standardized coefficient } & \multirow{2}{*}{$\begin{array}{c}\text { Standard coefficient } \\
\text { Beta }\end{array}$} & \multirow{2}{*}{$\mathbf{t}$} & \multirow{2}{*}{$\mathbf{p}$} \\
\hline & Beta & Std error & & & \\
\hline $\begin{array}{l}\text { Systematicity } \\
R^{2}:-0.015\end{array}$ & $\begin{array}{l}\quad-0.097 \\
\text { Corrected } R^{2}: 0.012\end{array}$ & $\begin{array}{c}0.043 \\
F: 5.058\end{array}$ & $\begin{array}{c}-0.123 \\
(p<0.001)\end{array}$ & -2.249 & 0.000 \\
\hline
\end{tabular}

The sports branches that students do have a $1.2 \%$ negative impact on their systematicity $(p<0.01)$. 
Table 6. Correlation analysis for the effects of the sports branches students do on the seekingthe truth, a sub-dimension of critical thinking levels.

\begin{tabular}{lccccc}
\hline \multirow{2}{*}{ Sports branches } & \multicolumn{2}{c}{ Non-Standardized Coefficient } & Standard coefficient & \multirow{2}{*}{ t } & p \\
\cline { 2 - 5 } & Beta & Std Hata & Beta & -0.136 \\
Seeking the truth & -0.146 & 0.053 & -2.493 & 0.000 \\
$R^{2}:-0.018$ & Corrected $R^{2}: 0.015$ & F: 6.217 & $(p<0.001)$ & & \\
\hline
\end{tabular}

Sports branches of students have $1.5 \%$ negative impact on their tendency to seeking the truth $(p<0.01)$.

Table 7. Correlation analysis for the effect of sports branches students perform on "self-confidence", a sub-dimension of critical thinking levels.

\begin{tabular}{lccccc}
\hline \multirow{2}{*}{ Sports branches } & \multicolumn{2}{c}{ Non-standardized coefficient } & Standard coefficient & \multirow{2}{*}{ t } & p \\
\cline { 2 - 5 } & Beta & Std Hata & Beta & & 0.000 \\
\hline Self-confidence & -0.098 & 0.048 &,- 112 & & -2.060 \\
$\mathrm{R}^{2}:-0.013$ & Corrected $\mathrm{R}^{2}: 0.010$ & $\mathrm{~F}: 4.425$ & $(\mathrm{p}<0.001)$ & & \\
\hline
\end{tabular}

Sports branches of students have a $1 \%$ negative impact on their self-confidence $(p<0.01)$.

\section{RESULTS AND DISCUSSION}

In this study, it was revealed that there is a relationship between students' critical thinking levels and academic success levels. In his study, Kökdemir (2003) concluded that as the students' critical thinking score increases, their academic performance increases, and more importantly, this increase is independent of the lesson type.

Kökdemir (2003) emphasizes that critical thinking can be gained through education, therefore, the necessity of an education model that is open to innovation, based on inquiry and where students act as active participants rather than passive receivers is very important for university education. Ip et al. (2000) and Shin (1998) show that critical thinking skills are effective in academic and clinical achievement, and nursing students with higher critical thinking scores are more successful in academic and clinical aspects. These results match THIS research findings.

In another study, Girot (2000) did not find a significant relationship between academic levels and critical thinking in his study, where he measured critical thinking at different academic levels. The result does not match this research findings.

In his book, "The Way Back to University: Thoughts and Expectations on Undergraduate Education at American Universities", Derek Bok, ex-president of Harvard University, said, "The goal of undergraduate education is not unique," If you need to include all aspects of student development in a comprehensive goal, then it does not matter whether these goals are narrow, very wide or practical to cover specific goals. "This statement draws attention to the key issues in the discussion process about the purpose of undergraduate education. He believes that the university is a critical period for students to develop extremely important qualifications. University education has many objectives. The objectives of the chosen university education should include: "Thinking ability, moral reasoning ability; citizenship awareness; Multicultural literacy; Global literacy; Broad interest; Preparation for employment Bok (2008).

The most striking result of the study is that there is a relationship between doing sports and critical thinking sub-dimensions. Bahadir et al. (2014), in a study they conducted on students, stated that the scores obtained from the act of critical thinking were higher in students engaged in active sports activities. This result overlaps with this research finding. Students' sports branches, their alternatives or tendency to evaluate different thoughts, and the possibility of asking questions are less likely to act objectively even when data are contrary to their thinking. Again, some branches of sports reduce students' confidence in their reasoning processes. Besides, the sports branches do reduce their organized, planned and careful research tendencies, albeit small.

Besides this, open-mindedness, does not affect the student's tolerance towards different approaches and sensitivity to his own mistakes, and curiosity, that is, the tendency of the student to acquire knowledge and learn new things without any expectation of gain and interest. Another situation to be discussed is the fact that students do any sports branch under a license does not have a positive or negative effect on their critical thinking structures. There is no relationship between students' truth-seeking sub-dimension levels, on the relationship between critical thinking sub-dimensions and academic achievement levels, as well as academic achievement levels.

Facione et al. (1995) found that students scored low on 
the truth-seeking subscale in their studies investigating critical thinking tendencies of 587 university students. As it is known, this sub-dimension aims to find the best and correct information, to be honest, and objective.

McBride et al. (2002) state that teacher candidates with a low tendency to seek the truth will teach the way they learn. In this context, tending to seek the truth for a teacher is important in terms of objectively evaluating different thoughts. It can be said that teacher candidates could not improve themselves sufficiently in this dimension or could not benefit from university education sufficiently.

There is a negative weak relationship between students' understanding of the truth on the relationship between critical thinking levels sub-dimensions and their sports branches, self-confidence, systematicity subdimension levels, and their sports branches. There is no relationship between students' sub-level of openmindedness, analyticity, curiosity and their sports branches.

Some researcher argue that knowing the concepts of a field, understanding how to form a good question and knowing that field will not be considered sufficiently critical, some general strategies can be applied to many fields, and critical thinking will be taught independent of content (Paul and Elder, 2002).

Under the light of the data obtained from the study, according to the evaluations of the students of Harvard University by Hua Haiyan about evaluating teachers in the curriculum, the first step to training critical thinkers in universities is to select and hire teachers who have the knowledge and skills to compare critical thinking with the faculty in the academic field. The appointment of top-level teachers requires a high level of scientific research, provided that general teachers have post-doctoral research experience. It is believed that high-level scientific research results are based on teachers' own good critical thinking abilities. In addition to the teacher selection and recruitment system, the teacher evaluation system will usually play a larger role in staff training. It is known that the dimensions of evaluating a teacher are versatile and that the weights of the various dimensions are different. If the scientific research level of the teacher is taken as an important standard and if more teachers will focus on training students, it will be difficult to achieve the goal due to conflicts of interest. In some developed countries, university teachers devote more time to teaching and teaching methods. According to the statistics of the US Department of Education, an average teacher spends more than half of his time on teachingrelated topics. And the time spent on scientific research is less than $20 \%$; more than $75 \%$ of the students are satisfied with the opportunity to discuss the subject between the undergraduate students and teachers (Haiyan, 2007). It is revealed that teachers are also important in university students' gaining critical thinking ability. Therefore, both in the school where sample individuals are identified, the fact that all the individuals are settled with the central system and the results obtained due to the absence of aptitude tests should be expanded and applied to include only other school students who take students with the aptitude test. Further studies should be conducted on students' evaluations of teachers in the curriculum. Closer estimates of the truth can be made by analyzing the data obtained from these studies.

\section{CONFLICT OF INTERESTS}

The author have not declared any conflict of interests.

\section{REFERENCES}

Aybek B (2006). Konu ve beceri temelli eleştirel düşünme öğretiminin öğretmen adaylarinin eleştirel düşünme eğilimi ve düzeyine etkisi (Doktora tezi, Tez No. 205450).

Bayram D (2015). The effects of WebQuest- supported critical thinking instruction on the critical thinking disposition level and L2 writing performance of Turkish pre-service EFL teachers (Yüksek lisans tezi, Tez No. 414401).

Bok D (2008). Üniversiteye Dönüş Yolu: Amerikan Üniversitelerinde Lisans Eğitiminin Yansimasi ve Beklentisi [M] Şanghay: Doğu Çin Normal Üniversitesi Yayinlari, 2008.

Coffman DM (2013). Thinking about thinking: An exploration of preservice teachers' views about higher order thinking skills (Doctoral dissertation). Retrieved from ProQuest Dissertations and Theses Global. (UMI No. 3567248).

Coşkun G (2011). Eleştirel düşünme eğitiminin müzik eğitiminde performansa etkisi (Doktora tezi, Tez No. 290728).

Çevik S (2013). An investigation of the critical thinking dispositions of pre-service teachers at a private non-profit university (Yüksek lisans tezi , Tez No. 356212).

Deniz E (2009). Öğretmen Adaylarinin Eleştirel Düşünme Beceri Düzeyleri Üzerine Bir İnceleme (Yüksek lisans tezi, Tez No. 258353).

Derrick-Telemaque E (2014). The relationship of academic achievement between critical thinking and associated dispositions: A canonical correlation analysis (Doctoral dissertation). Retrieved from ProQuest Dissertations \& Theses Global. (UMI No. 361297).

Doğanay A (2007). Üst düzey düşünme becerilerinin öğretimi. A Doğanay (Ed.), Öğretim İlke ve Yöntemleri içinde (ss.279-331) Ankara: Pegem Akademi.

Dolapci OC (2009). Öğretmenleri eleştirel düşünme konusunda bilgilendirmeye yönelik seminer çalişmasinin değerlendirilmesi (Yüksek lisans tezi). Yükseköğretim Kurulu Ulusal Tez Merkezi'nden edinilmiştir. (Tez No. 227467).

Facione PA, Facione NC, Giancarlo CA (1998). The California critical thinking disposition inventory test manual (revised). Millbrae, CA: California Academic Press.

Facione PA, Sanchez CA, Facione NC, Gainen J (1995). The disposition toward critical thinking. The Journal of General Education 44(1):1-25.

Girot EA(2000). Graduate nurses: Critical thinkers or better decision makers? Journal of Advanced Nursing 31:288-97.

Gülveren H (2007). Eğitim Fakültesi Öğrencilerinin Eleştirel Düşünme Becerileri Ve Bu Becerileri Etkileyen Eleştirel Düşünme Faktörleri (Doktora tezi, Tez No. 211603).

Güner C (2015). The Effects of critical- thinking based instruction on pre-service EFL teachers' critical thinking disposition level, English reading self- efficacy level, and English writing performance (Yüksek lisans tezi, Tez No. 414400).

Haiyan H (2007). Harvard Üniversitesi öğrencilerinin ders programlarindaki öğretmenleri ve değerlendirmeleri hakkindaki değerlendirmeleri [J] Yüksek Öğrenim Geliştirme ve Değerlendirme 1. 
Ip WY, Lee DTF, Lee IFK, Chau JPC.(2000). Disposition towards critical thinking: A study of chinese undergraduate nursing students. Journal of Advanced Nursing 32(1):84-90.

Kalayci N (2001). Sosyal bilgilerde problem çözme ve uygulamalar. Ankara: Gazi Kitabevi.

Kalelioğlu F (2011). Çevrimiçi tartişma yapisinin öğretmen adaylarinin eleştirel düşünme eğilimleri ile gerçek ve yansiyan eleştirel düşünme performanslarina etkisi (Doktora tezi, Tez No. 302030).

Kanbay Y (2013). Hemşirelik öğrencilerine verilen eleştirel düşünme eğitiminin problem çözme becerisi üzerine etkisi (Doktora tezi, Tez No. 384485).

Karakoç M (2011). The Critical Thinking Dispositions And Tendencies of Turkish EFL university students (Yüksek lisans tezi, Tez No. 302966).

Karali Y (2012). Eğitim Fakültesi Öğrencilerinin Eleştirel Düşünme Eğilimleri: İnönü Üniversitesi Örneği (Yüksek lisans tezi, Tez No. 314200).

Kasimoğlu T (2013). Öğretmen Adaylarinda Eleştirel Düşünme, Mantiksal Düşünme Ve Problem Çözme Becerilerinin Çeşitli Değişkenler Açisindan Değerlendirilmesi (Yüksek lisans tezi, Tez No. 333418).

Korur EN (2014). Beden Eğitimi Öğretmeni Adaylarinin Eleştirel Düşünme Ve Empatik Eğilimleri (Yüksek lisans tezi, Tez No. 381050).

Kökdemir D (2003). Belirsizlik durumlarinda karar verme ve problem çözme (Doktora tezi,Tez No. 127649).

Kökdemir D (2012). Üniversite eğitimi ve eleştirel düşünme. Pivolka 21:16-19.

McBride RE, Xiang P, Wittenburg D (2002). Dispositions toward critical thinking: The Preservice. teacher's perspective. Teachers and Teaching: Theory and practice $8(1): 29-40$.

Moreyra AA (1991). The role of thinking fram es in developing teachers' critical thinking skills and dispositions (Doctoral dissertation). Retrieved from ProQuest Dissertations, Theses Global. (UMI No. 0136492)

Nosich GM (2015). Eleştirel düşünme ve disiplinlerarasi eleştirel düşünme rehberi (B. Aybek, çev.), Ankara: Ani Yayincilik. (Çalişmanin orjinali 2012'de yayimlanmiştir.).

Obay M (2009). Problem çözme yoluyla eleştirel düşünme becerilerinin gelişim sürecinin incelenmesi (Doktora tezi, Tez No.278295).

Özdemir S (2005). WEB ortaminda bireysel ve işbirlikli problem temelli öğrenmenin eleştirel düşünme becerisi, akademik başari ve internet kullanimina yönelik tutuma etkileri. Doktora tezi, Tez No.206258.

Özen M (2013). Investigation of Pre-Service Mathematics Teachers' Critical Thinking Processes Through Statistical And Probabilistic Knowledge in the Context of Popular Media Texts. Yüksek lisans tezi, Tez No. 345132.

Öztürk N (2006). Hemşirelik Öğrencilerinin Eleştirel Düşünme Düzeyleri Ve Eleştirel Düşünmeyi Etkileyen Faktörler. Yüksek lisans tezi, Tez No. 196306.

Patrick JJ (1986). Critical thinking in the social studies. Retrieved from ERIC database. (ED272432).

Paul R, Elder $L$ (2006). The miniature guide to critical thinking: Concepts and tools. California, Tomales: Foundation for Critical Thinking.

Paul RW, Elder L (2002). Critical thinking: Tools for taking charge of your Professional life. Upper Saddle River, NJ: Prentice Hall.

Pirozzi R (2003). Critical reading, Critical thinking (2nd ed.). New York: Longman.
Schreglmann S (2011). Konu temelli eleştirel düşünme öğretiminin öğretmen adaylarinin akademik başari, eleştirel düşünme eğilimine ve düzeyine olan etkisi. Yüksek lisans tezi, Tez No. 300344.

Shin KR(1998). Critical thinking ability and clinical decision-making skills among senior nursing students in associate and baccalaureate programmes in Korea. Journal of Advanced Nursing 27(2):414-418.

Smith GF (2003). Beyond critical thinking and decision making: Teaching business students how to think. Journal of Management Education 27(1):24-51.

Tufan D (2008). Critical Thinking Skills of Prospective Teachers: Foreign language Education. Case at the Middle East Technical University Yüksek lisans tezi, Tez No. 227711).

Ünlü Ş (2017). Eleştirel düşünmeyi destekleyen öğretmen eğitimi programinin geliştirilmesi. Doktora tezi, Tez No. 481733.

Valdes-Corbeil ME (2005). The effect of the watson-glaser critical thinking appraisal test preparation program on the critical thinking of teacher education program applicants (Doctoral dissertation). Retrieved from ProQuest Dissertations AND Theses Global. (UMI No. 3165003).

Van Gelder T (2005). Teaching critical thinking: Some lessons from cognitive science. College Teaching 53(1):41-48.

Yağci R (2008). Sosyal bilgiler öğretiminde eleştirel düşünme: İlköğretim 5. sinif sosyal bilgiler öğretiminde, öğretmenlerin eleştirel düşünme becerilerini geliştirmek için uyguladiklari etkinliklerin değerlendirilmesi, Yüksek lisans tezi, Tez No. 217092.

Yeh $Y$ (1997). Teacher training for critical-thinking instruction via a computer simulation (Doctoral dissertation). Retrieved from ProQuest Dissertations and Theses Global (UMI No. 9724730). 